\title{
Erratum to: A phase II study of combined fulvestrant and everolimus in patients with metastatic estrogen receptor (ER)- positive breast cancer after aromatase inhibitor (AI) failure
}

\author{
Suleiman Massarweh • Edward Romond - Esther P. Black • \\ Emily Van Meter · Brent Shelton • Vera Kadamyan-Melkumian • \\ Mark Stevens $\cdot$ Richard Elledge
}

Published online: 21 January 2015

(C) Springer Science+Business Media New York 2015

Erratum to: Breast Cancer Res Treat (2014)

143:325-332

DOI 10.1007/s10549-013-2810-9

In the original publication, one adverse event (renal failuregrade 3) was inadvertently omitted from the final adverse event Table 3, when reconciling related vs. all adverse events on study. This event was reported during study conduct as unlikely related to study treatment, but should have been included in the final manuscript adverse events table.

The online version of the original article can be found under doi:10.1007/s10549-013-2810-9.

S. Massarweh · E. Romond

The Department of Internal Medicine, University of Kentucky, Lexington, KY, USA

S. Massarweh $(\varangle) \cdot$ E. Romond · E. P. Black · E. Van Meter ·

B. Shelton · V. Kadamyan-Melkumian · M. Stevens

Markey Cancer Center, University of Kentucky, cc452,

800 Rose Street, Lexington, KY 40536, USA

e-mail: massarweh@uky.edu

R. Elledge

University of Health Sciences Center at San Antonio,

San Antonio, TX, USA

R. Elledge

Cancer Treatment and Research Center (CTRC), San Antonio,

TX, USA 